\title{
A Study of Pyrite Acidification in Oil Sand Froth Treatment Tailings Deposits
}

\author{
Yuming $\mathrm{Xu}^{*}$ \\ Natural Resources Canada, CanmetENERGY-Devon, Canada
}

Submission: March 12, 2021; Published: April 01, 2021

*Corresponding author: Yuming Xu, Natural Resources Canada, CanmetENERGY, Devon, Alberta Canada T9G 1A8, Canada

\begin{abstract}
Pyrite acidification from froth treatment tailings was speculated to be of concern in the oil sands industry because froth treatment tailings (TSRU) contain a significant amount of the mineral pyrite. In this work bench-scale studies were conducted to investigate whether or not pyrite acidification occurs in TSRU tailings under laboratory controlled conditions, simulating the scenarios of (i) TSRU tailings under water in a tailings pond, and (ii) deposition on the beach. In the first case, the TSRU tailings were placed in a drum and covered with water for two years. In the second case, the TSRU tailings were placed in a glass tank and exposed to air. These tailings were subjected to wet-dry cycles, followed by a water leaching process. The chemistry of the original water and the leachate was determined and the mineralogy of the mineral solids before and after the drying-wetting cycles was measured. The results demonstrated that when TSRU tailings were kept under water for two years there was no change in the water chemistry, indicating no pyrite acidification. However, after the tailings had been exposed to air for an extended period of time, the $\mathrm{pH}$ of the leaching water decreased slightly, sulfate concentration increased significantly, and the pyrite content in mineral solids decreased; indicating that pyrite oxidation had occurred resulting in slight acidification.
\end{abstract}

Keywords: Pyrite oxidation; Acidic drainage; Oil sand tailings

\section{Introduction}

Acid rock drainage (ARD), also referred to as acid mine drainage (AMD), is an acidic effluent generated from sulfidic waste rock piles or tailings. It is a result of natural weathering processes caused by the oxidation of sulfide minerals, mainly pyrite or iron disulfide $\left(\mathrm{FeS}_{2}\right)$ [1]. ARD is a worldwide problem and has been identified as the largest environmental liability facing the Canadian mining industry. The amount of acid-producing mine wastes in Canada was estimated to be 2, 650 million tonnes, causing an environmental liability of $\$ 2$ to $\$ 5$ billion dollars [2]. Through the Mine Environment Neutral Drainage (MEND) Program, this liability has been reduced by at least $\$ 400$ million over eight years [3].

Previous research has revealed that when sulfide-containing minerals such as pyrite $\left(\mathrm{FeS}_{2}\right)$ are exposed to both moisture and air the minerals will oxidize spontaneously, with additional impacts from microbial activity resulting in production of acid [4-6]. In addition to the generation of high concentrations of $\mathrm{H}^{+}$, sulphate and soluble iron, the low $\mathrm{pH}$ effluent dissolves minerals and causes elevated concentrations of heavy metals, such as Se, $\mathrm{As}, \mathrm{Cu}, \mathrm{Zn}, \mathrm{Al}, \mathrm{Fe}$ and $\mathrm{Mn}$, which can be toxic and cause long-term effects to receiving streams [1].
The oil sands industry has raised concerns about the acidification of oil sands tailings resulting from the oxidation of pyrite-enriched froth treatment tailings (TSRU tailings) [7]. In this study, we conducted bench-scale tests on oil sands tailings to study whether the oxidation of pyrite in TSRU tailings occurs under two different situations including

a) TSRU tailings placed under water in a tailings pond, and

b) TSRU tailings deposited on a beach where the tailings are exposed to air and subject to natural wetting and drying cycles.

It has been reported that the acidity associated with ARD results from the action of Acidithiobacillus bacteria, which generate its energy by oxidizing ferrous iron $\left(\mathrm{Fe}^{2+}\right)$ to ferric iron $\left(\mathrm{Fe}^{3+}\right)$ using oxygen [8]. The ferric iron in turn attacks the pyrite to produce ferrous iron and sulfate. The ferrous iron is then available for oxidation by the bacterium; this cycle continues until the pyrite is depleted. The acidification can be described through the following reactions [4].

$$
\begin{aligned}
& 2 \mathrm{FeS}_{2}+7 \mathrm{O}_{2}+2 \mathrm{H}_{2} \mathrm{O} \rightarrow 2 \mathrm{Fe}^{2+}+4 \mathrm{SO}_{4}^{2-}+4 \mathrm{H}^{+} \\
& 4 \mathrm{Fe}^{2+}+\mathrm{O}_{2}+4 \mathrm{H}^{+} \rightarrow 4 \mathrm{Fe}^{3+}+2 \mathrm{H}_{2} \mathrm{O}
\end{aligned}
$$


Combining the above two equations gives Eq 3

$$
4 \mathrm{FeS}_{2}+15 \mathrm{O}_{2}+2 \mathrm{H}_{2} \mathrm{O} \rightarrow 4 \mathrm{H}^{+}+8 \mathrm{SO}_{4}^{2-}+4 \mathrm{Fe}^{3+}
$$

The $\mathrm{Fe}^{3+}$ released in reaction (2) or (3) may hydrolyze to form ferric hydroxide leading to the precipitation of iron hydroxide

$$
\mathrm{Fe}^{3+}+3 \mathrm{H}_{2} \mathrm{O} \rightarrow \mathrm{Fe}(\mathrm{OH})_{3} \downarrow+3 \mathrm{H}^{+}
$$

or may oxidize additional pyrite by the reaction:

$$
\mathrm{FeS}_{2}+14 \mathrm{Fe}^{3+}+8 \mathrm{H}_{2} \mathrm{O} \rightarrow 15 \mathrm{Fe}^{2+}+2 \mathrm{SO}_{4}^{2-}+16 \mathrm{H}^{+}
$$

The equations 3 and 4 can also be combined to give an overall equation

$$
4 \mathrm{FeS}_{2}+15 \mathrm{O}_{2}+14 \mathrm{H}_{2} \mathrm{O} \rightarrow 16 \mathrm{H}^{+}+8 \mathrm{SO}_{4}^{2-}+4 \mathrm{Fe}(\mathrm{OH})_{3} \downarrow
$$

Based on Eq 6, it can be seen that oxidation of pyrite $\left(\mathrm{FeS}_{2}\right)$ gives hydrogen protons $\left(\mathrm{H}^{+}\right)$, leading to the acidification of the water.

Since the tailings contain not only pyrite but also many other minerals such as carbonates $\left(\mathrm{CaCO}_{3}, \mathrm{MgCO}_{3}\right.$, and $\left.\mathrm{FeCO}_{3}\right)$, the acid produced may also react with other minerals:

$$
\mathrm{CaCO}_{3}+2 \mathrm{H}^{+} \rightarrow \mathrm{H}_{2} \mathrm{O}+\mathrm{CO}_{2}+\mathrm{Ca}^{2+}
$$

$$
\begin{aligned}
& \mathrm{MgCO}_{3}+2 \mathrm{H}^{+} \rightarrow \mathrm{H}_{2} \mathrm{O}+\mathrm{CO}_{2}+\mathrm{Mg}^{2+} \\
& \mathrm{FeCO}_{3}+2 \mathrm{H}^{+} \rightarrow \mathrm{H}_{2} \mathrm{O}+\mathrm{CO}_{2}+\mathrm{Fe}^{2+}
\end{aligned}
$$

Equations 7-9 indicate that every mole of carbonate reacting with acid will consume 2 moles of acid.

Based on Equations 1-9 the oxidation of pyrite can be detected by analyzing the mineralogy of the mineral solids (specifically, pyrite) and the leaching water chemistry. Decreasing solution $\mathrm{pH}$ and increasing dissolved sulfate $\left(\mathrm{SO}_{4}{ }^{2-}\right)$ and metal ion concentrations $\left(\mathrm{Ca}^{2+}, \mathrm{Mg}^{2+}\right)$ would be an indication of the pyrite oxidation.

\section{Material and Methods}

\section{TSRU tailings samples}

TSRU tailings samples used in this work were originally generated from froth treatment pilot tests conducted in CanmetENERGY's froth treatment facility. The composition of the original TSRU tailings was measured by Dean-Stark extraction (a modified Soxhlet extraction) and data are reported in Table 1. The original tailings sample collected from pilot runs were placed into drums.

Table 1: Composition of TSRU tailings used for pyrite oxidation experiments, measured by Dean-Stark extraction.

\begin{tabular}{|c|c|c|c|c|}
\hline \multirow{3}{*}{ Tailings Type } & \multirow{2}{*}{ Run } & Bitumen/Asphaltenes & Water & \multirow{2}{*}{ Mineral Solids (wt\%) } \\
\cline { 2 - 5 } & & $\mathbf{( w t} \%)$ & $\mathbf{( w t \% )}$ & 12.6 \\
\hline \multirow{3}{*}{ Original TSRU tailings } & 1 & 4.8 & 82.6 & 13.2 \\
\cline { 2 - 5 } & 2 & 5.3 & 81.4 & 12.9 \\
\hline \multirow{3}{*}{ TSRU tailings sediment } & Average & 5.1 & 43.5 & 41.6 \\
\cline { 2 - 5 } & 1 & 14.4 & 42.4 & 42.8 \\
\cline { 2 - 5 } & Average & 14.2 & 43 & 42.2 \\
\hline
\end{tabular}

After the tailings had stayed in the drum for a year, they were found to have formed four distinct layers including

(i) a top floating asphaltene particles layer,

(ii) a water layer,

(iii) a layer of stable clay suspension, and

(iv) a bottom sediment layers.

Minerals including pyrite, along with larger asphaltene aggregates, settled into the bottom sediment layer. During the year, the tailings were always covered with a top layer of water so that the minerals had no direct contact with air. The top three layers in one drum were separated from the bottom sediment layer. The sediment layer consisted of mainly asphaltenes and mineral solids. The sediment material was collected in a pail and homogenized. The composition of the tailings sediment was analyzed by Dean-Stark extraction and also reported in Table 1. The mineral solids fraction (i.e., solids collected from Dean-Stark) was analyzed for its mineral composition, including percentage pyrite by XRD. This sediment material was used for the oxidation test.

\section{Experimental setup and procedures}

\section{Tailings underwater}

The original TSRU tailings collected from the froth treatment pilot tests were placed in a drum which was tightly capped and stored at room temperature for two years. Water separated from the original TSRU tailings was collected (sample 1) and analyzed for ion concentrations. At the end of the second year, a water sample from the top water layer was collected (sample 2). After separating the top layers of asphaltene particles, water and clay suspension, the bottom sediment layer was collected 
and centrifuged to obtain a pore water sample (sample 3). The anion concentrations in the water samples were measured by ion chromatography and the dissolved metal concentrations (cations) were analyzed using inductively coupled plasma - mass spectrometry (ICP-MS) method.

\section{Tailings exposed to air}

Figure 1 shows the experimental setup for pyrite oxidation test. A glass tank (dimension $60 \mathrm{~cm} \times 36 \mathrm{~cm} \times 30 \mathrm{~cm}$ ) was used for containing the TSRU tailings. TSRU tailings sediment collected from the bottom of the drum was mixed to homogenize. Some of the sediment was placed in a centrifuge tube. After centrifugation, free water on the top of the tailings was collected as sample 1 (i.e., water prior to oxidation).

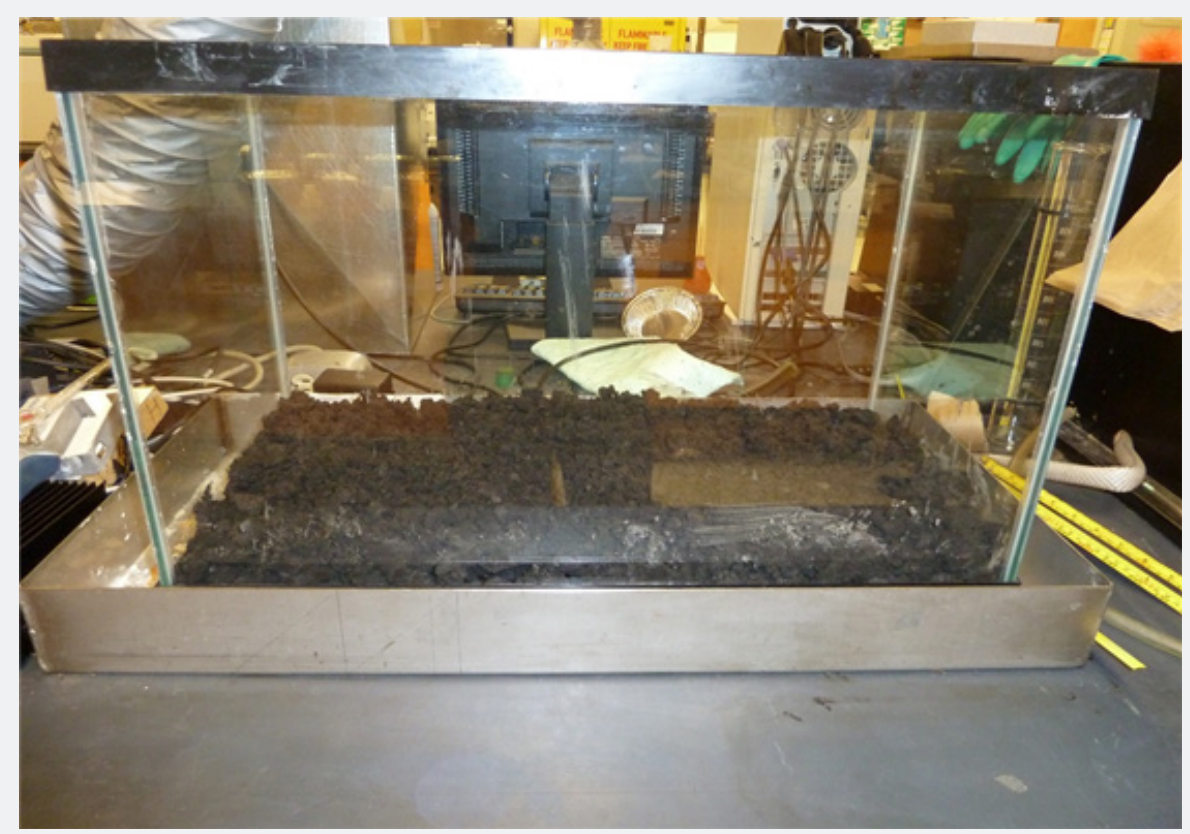

Figure 1: Experimental setup for pyrite oxidation tests in a glass tank.

The TSRU tailings sediment material was spread on the bottom of a glass tank as a flat layer approximately $4 \mathrm{~cm}$ thick, as illustrated in Figure 1. The container was open to the air for 2 weeks. After the first week the tailings became dry and mineral solids were exposed to the air.

After 2 weeks, a known amount of deionized (DI) water was added and mixed thoroughly with the dry tailing. After settling for a day, a layer of free water was then separated and collected as sample 2 (i.e., water after oxidization). The water was centrifuged to remove any particles.

The tailings remaining in the container were stored for another 4 weeks. At the end of 4 weeks, a known amount of DI water was added and mixed with tailings solids and the water was separated as sample 3 (i.e., water after $2^{\text {nd }}$ oxidization). All three water samples were analyzed for $\mathrm{pH}$, conductivity, and ion concentrations.

A subsample of the oxidized TSRU tailings was then collected from the tailings bed in the tank and the organic components were removed by Dean-Stark extraction. The mineral solids were analyzed for mineral composition by XRD. The degree of pyrite acidification was determined from the change of pyrite content in the mineral solids, as well as change in water chemistry.

\section{Mineralogy analysis}

The mineral solids sample obtained from the tailings by Dean-Stark extraction was wet ground in a micronizing mill with methanol for $5 \mathrm{~min}$ to reduce the particle size to less than $2 \mu \mathrm{m}$. The ground sample was then spray dried in Vertrel to obtain spherical particle with an average diameter of 2 to $5 \mu \mathrm{m}$. This treatment removed the need to correct for preferred orientation during Rietveld analysis.

X-Ray diffraction (XRD) analysis was carried out on a Rigaku D/MAX Rapid-II rotating anode powder diffractometer equipped with an image plate detector, using $\mathrm{CrK} \alpha$ radiation. Diffraction data was obtained at $35 \mathrm{kV}$ and $25 \mathrm{~mA}$, scanning from $5^{\circ}$ to $150^{\circ} 2 \theta$ with a scan step of $0.045^{\circ} 2 \theta$ for $0.2 \mathrm{~s}$. Quantification of the mineral species in the randomly oriented specimen was carried out using the Rietveld least square refinement program, AUTOQUAN ${ }^{\mathrm{TM}}$.

\section{Results and Discussion}

\section{Tailings under water}

As mentioned earlier, in order for the pyrite oxidation reactions to happen both oxygen and water are required. Lack of one of them would not lead to pyrite oxidation. In order to prevent 
oxidative dissolution of sulfidic minerals the tailings in mineral industry are frequently stored underwater to prevent exposure to air [1]. This is the scenario in the tailings pond where the tailings mineral solids are always under water. In our experiment the original TSRU tailings were stored under water for two years and therefore no oxidation was expected. Table 2 reported the $\mathrm{pH}$ and the ion concentrations in the water samples before and after two years.

Table 2: $\mathrm{pH}$ and ion concentrations in water from different samples collected from tailings under water test.

\begin{tabular}{|c|c|c|c|}
\hline & $\begin{array}{l}\text { Water in Original TSRU } \\
\text { Tailings }\end{array}$ & $\begin{array}{c}\text { Top Water Layer after two } \\
\text { years Storage }\end{array}$ & $\begin{array}{c}\text { Pore Water from Sediment Phase after two } \\
\text { years Storage }\end{array}$ \\
\hline pH & 8.6 & 8.67 & 8.62 \\
\hline Conductivity $(\mu \mathrm{s} / \mathrm{cm})$ & 1900 & 2300 & 2400 \\
\hline \multicolumn{4}{|l|}{ Anions (mg/L) } \\
\hline Bicarbonate $\left(\mathrm{HCO}_{3}\right)$ & 400 & 400 & 390 \\
\hline Carbonate $\left(\mathrm{CO}_{3}\right)$ & 14 & 18 & 25 \\
\hline Hydroxide $(\mathrm{OH})$ & $<0.5$ & $<0.5$ & $<0.5$ \\
\hline Dissolved Sulfate $\left(\mathrm{SO}_{4}\right)$ & 210 & 330 & 260 \\
\hline Dissolved Chloride $(\mathrm{Cl})$ & 235 & 260 & 300 \\
\hline \multicolumn{4}{|l|}{ Cations (mg/L) } \\
\hline Dissolved Calcium (Ca) & 8.4 & 5.4 & 9.6 \\
\hline Dissolved Iron (Fe) & $<0.1$ & $<0.1$ & $<0.1$ \\
\hline Dissolved Magnesium (Mg) & 4.2 & 3.3 & 5.1 \\
\hline Dissolved Manganese (Mn) & 0.02 & 0.01 & 0.03 \\
\hline Dissolved Potassium (K) & 8 & 11 & 13 \\
\hline Dissolved Sodium (Na) & 365 & 460 & 440 \\
\hline
\end{tabular}

As the results show, the $\mathrm{pH}$ in the three water samples is almost identical and the concentrations of sulfate, calcium and magnesium ions indicate no significant difference. This confirms that there was little to no pyrite oxidation in the two-year period during which the mineral solids were always under water and isolated from air.

\section{Tailings exposed to air}

Table 3: Water chemistry of the three water samples.

\begin{tabular}{|c|c|c|c|}
\hline & $\begin{array}{c}\text { Water in Initial TSRU Tailings Sediment } \\
\text { Phase }\end{array}$ & Water from $1^{\text {st }}$ Leaching & Water from $2^{\text {nd }}$ Leaching \\
\hline pH & 8.57 & 7.81 & 7.5 \\
\hline Conductivity $(\mu \mathrm{s} / \mathrm{cm})$ & 1700 & 2000 & 2600 \\
\hline \multicolumn{4}{|l|}{ Anions (mg/L) } \\
\hline Bicarbonate $\left(\mathrm{HCO}_{3}\right)$ & 670 & 74 & 78 \\
\hline Carbonate $\left(\mathrm{CO}_{3}\right)$ & 12 & $<0.5$ & $<0.5$ \\
\hline Hydroxide $(\mathrm{OH})$ & $<0.5$ & $<0.5$ & $<0.5$ \\
\hline Dissolved Sulfate $\left(\mathrm{SO}_{4}\right)$ & 17 & 820 & 1200 \\
\hline Dissolved Chloride $(\mathrm{Cl})$ & 190 & 110 & 84 \\
\hline \multicolumn{4}{|l|}{ Cations (mg/L) } \\
\hline Dissolved Calcium (Ca) & 8.4 & 83 & 220 \\
\hline Dissolved Iron (Fe) & $<0.06$ & 0.18 & 0.15 \\
\hline Dissolved Magnesium (Mg) & 4.7 & 40 & 74 \\
\hline Dissolved Manganese (Mn) & 0.039 & 0.56 & 1.2 \\
\hline Dissolved Potassium (K) & 8.8 & 11 & 11 \\
\hline Dissolved Sodium (Na) & 310 & 290 & 260 \\
\hline
\end{tabular}


In this test the TSRU tailings sediment was placed in a layer in the glass tank and subjected to drying-wetting cycles, where the tailings minerals were exposed to both air and water. In order to determine whether there was oxidation or acidification of pyrite we analyzed the chemical composition of the original water in tailings sediment, and the water leached from the first and second dry-wetting cycle. Table 3 summarizes the detailed water chemistry of the three water samples as described in 4.2.

The water analysis results revealed differences in the water chemistry between the original water and water after dry-wetting cycles. The $\mathrm{pH}$ in original tailings water was 8.4. It reduced to 7.8 in the leaching water after two weeks dry wetting. In the second drywetting cycle ( 4 weeks) the $\mathrm{pH}$ of the leaching water decreased to 7.5. The decrease in $\mathrm{pH}$ of the leachate indicates some degree of acidification of the pyrite based on Eqs. 4 and 6 .

It is interesting to observe that the dissolved sulphate concentration in the original tailings water was only $17 \mathrm{mg} / \mathrm{L}$. After the dry-wetting cycles, the sulphate concentration in the leaching water increased to 820 and $1200 \mathrm{mg} / \mathrm{L}$ respectively. According to Eq. 5 oxidation of each mole of pyrite molecules will produce 2 moles of sulphate. The significant increase in sulphate concentration in water further suggests the occurrence of the oxidation of the pyrite.

It was also noted that the calcium and magnesium ion concentrations in the water samples changed significantly. In the original tailings water, the calcium and magnesium concentration are 8.4 and $4.7 \mathrm{mg} / \mathrm{L}$, respectively. However, in the two leaching water samples, the calcium concentration increased to 83 and $220 \mathrm{mg} / \mathrm{L}$ and magnesium to 40 and $74 \mathrm{mg} / \mathrm{L}$, respectively. The increase in calcium or magnesium concentrations may be the result of the reaction represented by Eqs 7-8.

The mineral solids in the original TSRU tailings and in the tailings that were subjected to two cycles of oxidation were analyzed by XRD. The mineralogical compositions of the two samples are reported in Table 4.

Table 4: Mineralogy compositional of TSRU tailings solids determined by XRD analysis.

\begin{tabular}{|c|c|c|c|}
\hline & \multirow{2}{*}{ Mineral } & \multicolumn{2}{|c|}{ Total Solids Composition (wt \%) } \\
\hline & & Original Tailings (Sample 1) & Oxidized Tailings (Sample 3) \\
\hline \multirow{3}{*}{ Clays } & Kaolin & 16 & 19.3 \\
\hline & Illite & 8.1 & 6.2 \\
\hline & Chlorite & 1.8 & 0.5 \\
\hline \multirow{2}{*}{ Carbonates } & Calcite $\left(\mathrm{CaCO}_{3}\right)$ & 1 & 0.6 \\
\hline & Siderite $\left(\mathrm{FeCO}_{3}\right)$ & 8 & 6.3 \\
\hline \multirow{5}{*}{ Titanium oxides $\left(\mathrm{TiO}_{2}\right)$} & Anatase & 1.1 & 3.1 \\
\hline & Rutile & 3.6 & 5.4 \\
\hline & Pyrite $\left(\mathrm{FeS}_{2}\right)$ & 6.1 & 5.1 \\
\hline & Zircon & 1.4 & 3 \\
\hline & Quartz $\left(\mathrm{SiO}_{2}\right)$ & 52.9 & 50.5 \\
\hline
\end{tabular}

The results in Table 4 show that the pyrite content in the mineral solids of original tailings is about $6.1 \mathrm{wt} \%$. After two cycle of oxidation the pyrite content in the mineral solids was about $5.1 \%$. The results indicate that the pyrite content in mineral solids of the tailings that had subjected two dry-wetting cycles is lower than that in the original tailings, indicating some oxidation of pyrite. However, due to the heterogeneity of the sample, the way the sample was taken, as well as the experimental uncertainty, we should not quantify the oxidation of pyrite based on the percent of the pyrite content in the solids.

After completion of the bench tests, CanmetENERGY had collaborated with oil sand industry partners and conducted a pilot-scale deposition tests to further investigate the acidic drain of TSRU tailings. The results will be reported separately.

\section{Conclusion}

The TSRU tailings placed under water for two years did not exhibit any pyrite oxidation. When the TSRU tailings were subjected to two wetting-drying cycles, a small amount of the pyrite was oxidized leading to slight acidification of the leachate. This is evidenced from the changes in $\mathrm{pH}$ and water chemistry of the leachate, and the reduced pyrite concentration in the tailings. The $\mathrm{pH}$ of the water changed from 8.6 in the original water to 7.5-7.8 in the leachate after oxidation. The leachate contained significantly higher sulphate concentrations than the original water. The high sulphate concentration is the result of the oxidation of the pyrite mineral.

\section{Acknowledgement}

The author thanks Surjit Thind and Edwina Ngo for their 
assistance in conducting some of the experiments and Dr. Michael Afara for his help in XRD measurements. Financial support from the Program of Energy Research and Development (PERD), Natural Resources Canada, is acknowledged.

\section{References}

1. Jennings SR, Neuman DR, Blicker PS (2008) Acid Mine Drainage and Effects on Fish Health and Ecology : A Review. Reclamation Research Group, LLC, Bozeman, Montana

2. Tremblay GA, Hogan CM (2001) MEND Manual Volume 2-Sampling and Aanlysis MEND 5.4.2b, Ottawa, ON, Canada.

3. WA Price (2009) Prediction Manual for drainage Chemistry from Sulphidic Geologic Material. MEND Report 1.20.1, Natural Resources Canada.
4. Garcia C, Ballester B, Gonzalez F, Blazquez ML (2005) Pyrite behaviour in a tailings pond. Hydrometallurgy 76(1-2): 25-36.

5. Johnson DB, Hallberg KB (2003) The microbiology of acidic mine waters. Res Microbiol 154(7): 466-473.

6. Price B (1995) Defining the AMD Problem: II. An Operator's Perspective" In: Proceedings of the 2nd Australian Acid Mine Drainage Workshop, Charters Towers, Queensland, Australia.

7. Lindsay BJ, Vessay CJ, Robertson JM (2019) Mineralogy and geochemistry of oil sands froth treatment tailings: Implications for acid generation and metal(loid) release. Applied Geochemistry 102: 186-196.

8. Lee ES, M Hendry J, Hollings P (2003) Use of $\mathrm{O}_{2}$ consumption and $\mathrm{CO}_{2}$ production in kinetic cells to delineate pyrite oxidation-carbonate buffering and microbial respiration in unsaturated media. Journal of Contaminant Hydrology 65(3-4): 203-217.

\section{Your next submission with Juniper Publishers} will reach you the below assets

- Quality Editorial service

- Swift Peer Review

- Reprints availability

- E-prints Service

- Manuscript Podcast for convenient understanding

- Global attainment for your research

- Manuscript accessibility in different formats ( Pdf, E-pub, Full Text, Audio)

- Unceasing customer service

Track the below URL for one-step submission https://juniperpublishers.com/online-submission.php 